\title{
Obituary: \\ Kela Kvam 1931-2019
}

Kela Kvam, co-founder of the Association for Nordic Theatre Scholars and the Nordic Theatre Studies journal, from 1974-2001 Department Chair and Professor of Theatre Research at the University of Copenhagen, passed away on 14 July 2019.

Kela Kvam's research includes publications on Strindberg, European avant-garde theatre, Max Reinhardt, German and Danish workers' theatre in the interwar years and Danish group theatre as well as an extensive biographical study of the Danish actress, stage director and theatre manager Betty Nansen (1973-1943). She was the co-author and co-editor of the two-volume edition Dansk Teaterhistorie (199293) and an important contributor to Dansk Kvindebiografisk Leksikon (2000-01) as well as Gyldendals Teaterleksikon (2007).

Kela held MA degrees in both literature and theatre. Apropos the tradition heralded by the University of Copenhagen's first professor of Theatre Research, Torben Krogh, who sought to distance the discipline from Literary Studies in order to privilege performances over dramatic writing, it could be claimed that she flirted with the enemy. It meant, however, that the dramaturgs-in-spe gained a strong sense of world drama.

Moving from an associate professorship at Odense University, Kela arrived at a small institute, where most of her colleagues had been her peers as students under Torben Krogh - and all of whom had applied for the vacant chair. It was, moreover, a divided department following the short visit from 1970-72 by the Swedish professor Ingvar Holm, who sought to veer the education in a sociological direction. More than anything it was Kela's forte that she could build on the tradition from Torben Krogh while continuing the rejuvenation introduced by Ingvar Holm. The renewal, however, did not take place without a struggle - it was after all in the wake of 1968. The fact that Kela often sided with the revolutionary students on the study board did not lessen the resistance.

Kela's teaching was largely tied to her research and she involved her students not only in working with source material, but also in collecting and generating 
data. Another characteristic was the priority given to communication: In the mid 1970s it was extraordinary for a professor to place so much faith in her students that she would ask them to arrange exhibitions and lecture to organisations, make radio and TV-programs for school pupils and organise festivals and international guest performances.

The prim institution of Copenhagen University was not geared to this kind of an opening up towards the surrounding world, and the Rector's office responded with firm requests to bring the externally directed activities to a stop. A contributing factor was perhaps the exhibition on group theatre in the town hall of the conservative municipality of Frederiksberg in 1975 that featured posters of theatre performances providing information about sex, costumes from Solvognen's Julemandshæren (eng. Father Christmas Army) and last but not least, a big anti-EU-octopus, which resulted in the Danish politician Erhard Jacobsen from Aktiv Lytterkomité (Active Listeners' Committee) calling her 'the fox red theatre professor" ("den ræverøde teaterprofessor").

A further product of her interest in Danish group theatre of the 1970s was the Documentation Centre for Nordic Group Theatre, an archive based on the students' collection of source material through interviews, photographs, and tape recordings of performances. The material is currently stored at the Department of Arts and Cultural Studies, Copenhagen University and will eventually be transferred to the Royal Danish Library.

To Kela, opening up Theatre Science to the world also involved looking beyond the Eurocentrism of the discipline. Towards the end of the 1970s, she took a group of students and a film crew to Nigeria to meet with the Nigerian playwright Wole Soyinka, who had just been released from prison.

In the 1980s and 90s the spectacular happenings outside the university were fewer - even if the level of activity was still high. In 1998 she was involved in founding the Association for Nordic Theatre Scholars (Nordiske Teaterforskere) and the journal Nordic Theatre Studies in 1988. Her commitment to political theatre was transformed into a commitment to cultural politics when she was appointed by the Danish Cultural Minister to the Theatre Council and other national bodies. At the university she organised several international conferences, among these a Strindberg symposium and a conference on marionette theatre and also initiated a collaboration with the National Theatre School. The students from her later years remember Kela for her vast and up to date knowledge, her sharp observations as well as her understated and at times piercing sense of humour.

As a pensioner, Kela enjoyed her retirement but never relinquished her scholarly interests. Nor did she abstain from provoking the establishment: based on her research into The Federal Theatre under the New Deal, she published an essay in the daily newspaper Information in 2013 about Roosevelt's Works Progress Administration, in which she suggested that Europe's leaders should learn from a president who was committed to fighting for those in need.

This obituary is presented on behalf of the academic staff at the section of Theatre and Performance Studies, Department of Arts and Cultural Studies, University of Copenhagen. 